\title{
WYKŁAD WPROWADZAJĄCY NA VI SYMPOZJUM IM. MINISTRA KRZYSZTOFA SKUBISZEWSKIEGO*
}

Szanowny Panie Rektorze, Drodzy Państwo, dziękuję za zaproszenie i wspólne przypomnienie nie tylko dorobku, ale i sposobu działania oraz myślenia ministra Krzysztofa Skubiszewskiego. Dla mnie jest to również okazja do trochę osobistych wyznań i osobistego podziękowania. Wtedy na przełomie ustrojowym normą był, w kręgach solidarnościowych ministrów, rewolucyjny życiorys i rewolucyjny styl życia. Wtedy dopiero kształtowała się nowa polska obyczajowość polityczna, przyniesiona przez nowe środowiska solidarnościowe, tak gdzieś pomiędzy swetrem Jacka Kuronia a elegancja, trochę staroświecka, ministra Krzysztofa Skubiszewskiego. To mi szalenie odpowiadało i za to też jestem do dzisiaj wdzięczny, bo gdzieś za tym kryło się, z jednej strony, poczucie potrzeby głębokiej ideowości, która niesie za soba powiew rewolucji, w parze z potrzebą kontynuacji, z potrzebą stawiania na profesjonalność, stawiania na wiedzę, doświadczenie i także na takie właśnie trochę staroświeckie, nie zawsze modne myślenie w kategoriach nie tylko tego, co jest pożądane, ale również tego, co jest możliwe, co jest realne z punktu widzenia wiedzy i doświadczenia, i logicznego odczytywania znaków współczesności.

Pan Krzysztof Skubiszewski darzył mnie sympatia. Pamiętam taką rozmowę, gdy był już sędzią w Hadze. „Panie ministrze, ja na Pana głosuję, nie tylko dlatego, że znam Pan ojca i Pana rodzinę, ale dlatego, że Pan się dobrze zapowiada. Ale ja nie tylko na Pana głosuję, ja Pana także obserwuję". Mam wrażenie, że Pan Krzysztof nas wszystkich w dalszym ciąu trochę obserwuje, patrzy, a my również powinniśmy w stopniu maksymalnie możliwym pracować, tak aby nie zatracić poczucia odpowiedzialności za przyszłość Polski i przyszłość świata, starać się także gdzieś w przeszłości szukać wzorców wartych pamiętania, wartych także ciąłego analizowania. To chyba było istotnym doświadczeniem całej ekipy, która jako pierwsza podjęła próbę zmienienia Polski nie na drodze rewolucji, ale na drodze ewolucji i kompromisu politycznego, na drodze ciężkiej pracy i poszanowania różnorodności życiorysów. To było odpowiednie wyczucie proporcji między marzeniami

* VI Sympozjum im. Ministra Krzysztofa Skubiszewskiego pt. „Kryzys demokracji liberalnej i polityka zagraniczna" odbyło się 6 marca 2017 r. na Uniwersytecie Warszawskim. Sprawozdanie z Sympozjum opublikowano w niniejszym zeszycie RPEiS na s. 221-222 (przyp red.). 
a realizmem, także w obszarze polityki zagranicznej. I myślę, że to co jest nam wszystkim najbardziej potrzebne w tej chwili, to jest to myślenie w kategoriach zarówno utrzymania marzeń, jak i utrzymania wiary, że te nasze ideały, nasze własne dokonania na trudnej drodze ku realizacji marzeń muszą być stale pozytywnie weryfikowane, że nie muszą padać ofiarą płaskiego realizmu czy odczytywania tylko znaków współczesności.

I myślę, że jest to szczególnie dzisiaj potrzebne, kiedy zastanawiamy się nad tym, co stało się naszym udziałem dzisiaj, co stało się udziałem całego pokolenia, czy też całych pokoleń zaangażowanych w projekt wmontowywania Polski w integrację europejska. Dlatego temat dzisiejszego spotkania jest ważny i w wymiarze politycznym, i w wymiarze ideowym. Oczywiście pytanie, czy Europa jest w kryzysie, jest bezsensowne, bo to oczywiste, że Europa jest w kryzysie, wszyscy to widzimy, wszyscy to czujemy. Widzimy, że ten kryzys jest na tyle poważny, bo daje o osobie znać naraz w paru istotnych obszarach. Trzeba jednak w imię romantycznego podejścia do polityki, trochę utrzymania naszych marzeń i naszego optymizmu pamiętać, że Europa zawsze przeżywała kryzysy. Można powiedzieć więcej, Europa rozwijała się przez przezwyciężanie kryzysów. Projekt europejski stale wzbogacał się przez doświadczenia zdobywane często w dramatycznych sytuacjach kryzysowych. Można zatem powiedzieć, że nie ma postępu, także w obszarze integracji europejskiej, bez kumulowania doświadczeń z przełamywania, przekraczania i pokonywania kolejnych zjawisk kryzysowych.

Nasz problem polega na tym, że chyba nigdy dotąd w historii tak wiele kryzysów, i to tak poważnych, nie wystapiło jednocześnie. Dzisiaj mamy kryzys ekonomiczny i tożsamościowy, który dał o sobie znać poprzez kryzys imigracyjny. Mamy kryzys spowodowany wydarzeniami na wschodzie Europy - agresję Rosji na Ukrainę. Mamy kryzys związany z Brexitem. Mamy też kryzys, który nie dotyczy tylko Europy, ale całego świata Zachodu. Bo słusznie jest rozważany problem kryzysu demokracji liberalnej. Chociaż w żadnym dokumencie UE nie jest zapisane, że integracja europejska jest wymysłem czy też pomysłem demokracji liberalnej i że zadaniem integrującej się Europy jest upowszechnianie i umacnianie tylko i wyłącznie takiego modelu demokracji, ale tak naprawdę w wymiarze praktycznym tak właśnie było i tak jest nadal. Pomysł na integrację europejską był logicznie zwiazany z tym, co przyjęło się definiować jako demokrację liberalną opartą na zasadach wolności - wolności politycznej, wolności jednostki i w końcu wolności ekonomicznej. Zbudowano integrację europejska, wychodząc od zbudowania wspólnoty opartej na wolności ekonomicznej, na swobodnym przepływie kapitału, ludzi i usług. Do tego dobudowywano kolejne segmenty związane z bezpieczeństwem politycznym, gospodarczym. My także w roku 1989 za przyczyną m.in ministra Krzysztofa Skubiszewskiego dokonaliśmy jednoznacznego wyboru. Dokonaliśmy nie tylko wyboru na rzecz naszej polskiej wolności, ale dokonaliśmy także wyboru co do uczestnictwa w projekcie Europa liberalna, mówiąc, że chcemy iść na Zachód, że chcemy uczestniczyć w integracji europejskiej. Dokonując wyboru ustroju politycznego, dokonaliśmy wyboru modelu rozwojowego. Wtedy na ten temat dyskusji specjalnie 
nie było. Ona nie była konieczna, bo z całym szacunkiem dla ludzi, którzy działali w ramach rzeczywistości peerelowskiej, to jednak wszyscy, łącznie z funkcjonariuszami komunistycznej władzy, wiedzieli, że na Zachodzie jest lepiej niż na Wschodzie. Jak ktoś uciekał, to nigdy na Wschód, tylko na Zachód. Wszyscy to wiedzieliśmy, wszyscy to czuliśmy, dla wszystkich było to jasne, że kapitalizm jest lepszy niż socjalizm. Dla wszystkich było oczywiste, że na Zachodzie jest wolność, a na Wschodzie - opresja. W związku z tym jakiejśs specjalnej dyskusji nie było, poniekąd dokonaliśmy z automatu wyboru. Było oczywiste, że pod wieloma względami trzeba przejąc sprawdzony model świata zachodniego. Kierunek był oczywisty i właśnie dlatego, nie tylko przy Okragłym Stole, ale i w ramach rządów, w których ministrem spraw zagranicznych był Krzysztof Skubiszewski, znaleźli się ludzie o bardzo różnych życiorysach i o bardzo różnych poglądach. Był i socjalista Jacek Kuroń, konserwatysta Olek Hall, znalazł się i Leszek Balcerowicz, zwolennik zdecydowanego pójścia w stronę wolnorynkowej gospodarki, bo wiedział, że żadnej trzeciej drogi nie ma. I znaleźli się ludzie, którzy nieśli w sobie doświadczenia bankructwa i świadomość kresu poprzedniego systemu - systemu realnego socjalizmu - w wymiarze moralnym, politycznym, a także gospodarczym. Według mnie warto o tym pamiętać, że wtedy dokonaliśmy całościowego wyboru na Zachód, jak najdalej od socjalizmu, jak najbliżej demokracji liberalnej. Kierunek na Zachód oznaczał integrację europejską. Integracja europejska oznaczała zaś wejście w logikę myślenia o ustroju państwa, o ustroju gospodarczym, który definiowany jest przez ogólne pojmowanie demokracji liberalnej. Warto o tym pamiętać i o tym sobie przypominać $\mathrm{w}$ sytuacji, kiedy ten kierunek jest dzisiaj kwestionowany z różnych stron, z różnych pozycji. Wydawałoby się, że czasami przeciwstawnych i wrogich sobie. Jest bowiem kwestionowany model demokracji liberalnej i wolnościowy kierunek integracji europejskiej i z lewa, i z prawa jednogłośnie.

Co w tej sytuacji zrobić? Warto rozmawiać, dyskutować, ale warto również pamiętać, że tak naprawdę, każdy w wymiarze indywidualnym, ale także zbiorowo, jako społeczeństwo, stoi w obliczu pytania, czy mamy cokolwiek innego do zaoferowania, coś nowego, coś odmiennego. Czy jesteśmy w stanie wymyślić coś równie logicznego, atrakcyjnego, równie ambitnego i jeszcze na dodatek sprzyjającego naszym interesom narodowym, społecznym i interesom całego świata zachodniego? Dzisiaj, kiedy słyszę bardzo liczne głosy krytyki z lewej i z prawej dotyczace modelu integracji europejskiej, modelu demokracji, wolnego rynku, to mówię - proszę bardzo, jeśli ktoś ma lepszy pomysł, niech położy go na stole, niech podda go krytyce i dyskusji. W moim przekonaniu nie ma bowiem żadnego nowego rozwiązania ani nie ma realnej i efektywnej drogi pomiędzy socjalizmem a demokracją. Dlatego do fantazji politycznych należy zaliczyć m.in. pomysły dotyczące zmiany traktatów Unii Europejskiej. Do fałszywych tropów trzeba także zaliczyć pomysły na gwałtowne zmiany w istotnych obszarach funkcjonowania integracji europejskiej. Proszę Państwa, jak się nie wie, jak się zachować, to trzeba zachować się przyzwoicie. Mamy sprawdzone wzorce, to jest nasze doświadczenie pokoleniowe, myśmy dokonali tej zmiany i póki co - w moim 
przekonaniu - nikt trzeciej drogi nie wymyślił. Oczywiście nie znaczy to, że wszystko musi zostać po staremu. Musi to oznaczać myślenie krytyczne o tym, gdzie można znaleźć źródła siły na przyszłość, tak aby projekt zarówno demokracji liberalnej, jak i projekt integracji europejskiej kontynuować, rozwijać i zyskiwać dla niego poparcie. Należy mieć świadomość, że dzisiaj kwestionowane sa fundamenty projektu europejskiego i fundamenty projektu demokracji liberalnej, np. problem wolności ekonomicznej i źródło potęgi gospodarczej Europy.

Pamiętajmy więc, że integracja Europy była projektem wolnościowym i w moim przekonaniu musi taką pozostać.

Dziś modna jest wizja Europy socjalnej, tylko trzeba się zastanowić, co to oznacza w realiach polskich. Co to oznacza w kwestii mechanizmów związanych z bezrobociem, z płacami, z prawami pracowniczymi? Zatem musimy mieć świadomość, co to oznacza dla szans dogonienia przez Polskę głównych państw europejskich. Dzisiaj już wiemy, czym jest integracja europejska, wiemy, czym jest demokracja liberalna, ale i musimy wiedzieć, co oznacza i jakie przyniesie skutki odejście od niej w takiej czy innej kwestii. Musimy rozważać wszystko z pozycji, co to oznacza dla szans polskich, bo w UE można myśleć w kategoriach wspólnoty europejskiej, wspólnoty całego świata zachodniego, ale można i należy łączyć to z myśleniem w kategoriach interesu narodowego, inaczej go definiując niż ci, którzy mówią dziś, że chcemy wstać z kolan, że chcemy zakwestionować właśnie wolnościowy charakter integracji i wolną gospodarkę w imię uszczęśliwiania narodu. Należy zatem zastanowić się, jak przyciagnąć ludzi, którzy są wrażliwi na kwestie wizji Europy socjalnej. Jednak my w Polsce, tak samo jak w roku 1989, musimy na wszystko patrzeć z punktu widzenia tego, czy to nas zbliża, czy oddala od perspektywy dogonienia Europy Zachodniej. Możemy sobie opowiadać o tym, co byśmy chcieli, aby się zmieniło w integracji europejskiej, ale zawsze musimy to oceniać - czy to oznacza spowolnienie doganiania bogatszej części świata zachodniego, czy przyśpieszenie. My byliśmy i nadal jesteśmy narodem na dorobku. Mieliśmy gigantyczną szansę. Obawiam się, że powoli zaczynamy ją tracić, nie tylko na integrację w wymiarze politycznym, ale także i w wymiarze gospodarczym, pozwalającym na posiadanie nadziei na przyśpieszone tempo rozwoju.

Proszę Państwa, dyskutować trzeba, ale według mnie trzeba trzymać się dwóch zasad: realizmu politycznego i zasady myślenia o tym, co to przyniesie w wymiarze interesu narodowego społeczeństw będących na etapie dorabiania się i nadganiania gigantycznych zaległości.

Proszę Państwa, to u Wyspiańskiego jest piękne zdanie Wiele byśmy mogli mieć, byle byśmy chcieli chcieć. Przed takim wyzwaniem staliśmy do tej pory. To było nasze wyzwanie przez ostatnie 25 lat wolności. Wiele mogliśmy mieć, nie zawsze chcieliśmy chcieć. Mam na myśli kwestię strefy euro i wiele innych strategicznych wyzwań stojących przed Polska. Dzisiaj obawiam się, że z Wyspiańskiego coraz częściej będzie można nam wszystkim przytaczać inny cytat: miateś chamie złoty róg. Ten róg jest już coraz dalej i coraz dalej są możliwości racjonalnego, zgodnego z polskim interesem narodowym 
współkształtowania procesu integracji europejskiej i współkształtowania także demokracji liberalnej.

Życzę Państwu ciekawej dyskusji i sam jestem bardzo zainteresowany nie tylko rozłożeniem się opinii, ale również tym, czy potrafimy wyłamać się z myślenia w kategorii stereotypów lewicowych, prawicowych, konserwatywnych po to, aby szukać rozwiązań optymalnych z dwóch punktów widzenia: polskiej racji stanu i marzeń o wielkości świata zachodniego.

Dziękuję bardzo.

Bronistaw Komorowski

Prezydent Rzeczypospolitej Polskiej 2010-2015 
